\title{
PENERAPAN ALAT TES BUTA WARNA BERBASIS ARDUINO UNO
}

\author{
Januardi Nasir \\ Fakultas Teknik dan komputer, Program Studi Teknik Informatika \\ Universitas Putera Batam \\ Email: januardinasir@gmail.com \\ Christian Difo \\ Program Studi Teknik Informatika \\ Universitas Putera Batam \\ Email: christiandifo@gmailcom
}

\begin{abstract}
ABSTRAK
Dari perkembang zaman yang modern ilmu pengatahuan dan teknologi berkembang sangat pesat sehingga dengan beberapa peralatan yang menggunakan mesin dan elektronik kini sudah bisa dikendalikan misalnya dengan sensor. Sensor merupakan jenis tranduser yang digunakan untuk mengubah besaran mekanis, magnetis, panas, sinar, dan kimia menjadi tegangan dan arus listrik. Sensor sering digunakan untuk pendeteksian pada saat melakukan pengukuran atau pengendalian. Tujuan dari penelitian ini adalah menerapkan alat tes buta warna dengan menggunakan mikrokontroller secara otomatis untuk menghindari prosedur yang cukup lama, selain itu menerapkan mikrokontroller atmega 328 sebagai alat tes buta warna untuk menghindari kemungkina kesalahan yang dikerjakan secara manual oleh petugas, dan menerapkan infrared IR wireless remote control sebagai petugas pengawas. Alat tes buta warna yang dibuat ini menggunakan IR remote yang berfungsi sebagai mengirimkan angka yang nantinya akan ditampilkan kedalam LCD display. Setelah angka diinput nanti motor servo akan melakukan putaran untuk menggulung kertas sesuai dengan urutan angka tes buta warna ditahap simpan jawaban setelah pengguna menekan tombol ok maka arduino akan melakukan pemprosesan perhitungan dan mengeluarkan nilai keluar pada output pada thermal printer. Setelah dilakukan pengujian alat tes buta warna ini bekerja dengan baik.. Alat ini berfungsi sebagai alat yang otomatis karena adanya Infrared IR wireless remote control sehingga bisa diatur dari jarak jauh.
\end{abstract}

Kata kunci: arduino; ir remote; tes buta warna.

\begin{abstract}
The modern era of developments in science and technology is evolving very rapidly so that with some equipment that uses electronic engine and now could be controlled by sensors. Tranduser is a type of sensor that is used to change the quantity of a mechanical, magnetic, heat, rays, and chemistry into the voltage and electric current. Sensors are often used for detection at the time of measurement or control. The purpose of this research is to apply a color blindness test tool using mikrokontroller automatically to avoid a procedure long enough, besides applying mikrokontroller atmega 328 as a tool to avoid color blindness test "possible errors are carried out manually by the clerk, and applying infrared IR wireless remote control as a supervisor. Color blindness test tools that were created using the IR remote that functions as sending the numbers that later will be shown into the LCD display. After inputted numbers later servo motor will do rounds for rolled paper in accordance with order number ditahap color blindness test save an answer after the user presses the ok button then the Arduino will do the processing calculation and issue the value of the out on the output on the thermal printer. After testing this color blindness test tool work properly. .. This tool serves as a tool that automatically due to Infrared IR wireless remote control so it can be arranged from a distance.
\end{abstract}

Keywords: arduino; ir remote; color blind test.

\section{PENDAHULUAN}

Dari perkembang zaman yang modern ilmu pengatahuan dan teknologi berkembang sangat pesat sehingga dengan beberapa peralatan yang menggunakan mesin dan elektronik kini sudah bisa dikendalikan misalnya dengan sensor. Sensor merupakan jenis tranduser yang digunakan untuk mengubah besaran mekanis, magnetis, panas, sinar, dan kimia menjadi tegangan dan arus listrik. Sensor sering digunakan 
untuk pendeteksian pada saat melakukan pengukuran atau pengendalian. Disini pendengendalian menggunakan mata.

Berdasarkan hasil wawancara dengan dokter specialis mata di Rumah Sakit Budi Kemulian Batam. Hasil data kunjungan pasien buta warna Rumah Sakit Budi Kemuliaan Batam dari tahun 2013 sampai 2017 terdapat kunjungan pasien terbanyak di tahun 2017 sebanyak 70 pasien dari pada tahun sebelumnya. Metode yang digunakan dokter Rumah Sakit Budi Kemulian untuk pelaksanaan atau penerapan tes buta warna di Rumah Sakit masih manual dengan mengunakan buku Ishihara untuk pemeriksaan pasien apabila tidak mumpuni akan dirujuk ke poli untuk tindak lanjut ke dokter spesialis mata. Kendala atau keluhan dokter pada saat melakukan tes buta warna masih manual untuk pengujian ke pasien. Penerapan metode rumah sakit Budi Kemulian masih menggunakan buku ishihara tidak pakai alat khusus dan standart kompetensi Dokter mata harus bisa. Dokter setuju untuk dibuatkan alat yang otomatis untuk mendekteksi buta warna. Dengan alat tersebut sudah sangat membantu melengkapi fasilitas tes buta warna di rumah sakit Budi Kemuliaan secara cepat tepat dan efisien dan tidak harus membuang banyak waktu. Tes buta warna sangat dibutuhkan baik perusahaan akan merekut tenaga kerja tertentu yang tidak buta warna. Ketika seorang penderita buta warna masuk ke departemen tertentu maka akan sangat merugikan perusahaan baik internal maupun external. Pada saat bekerja di bidang yang harus mengenal warna dengan benar penderita buta warna tidak akan bisa bekerja dengan maksimal. Pada bidang departemen network engineering dituntut agar mengenal warna pada kabel untuk membuat konfigurasi kabel tertentu seperti cross cable and straight cable warna pada kabel diurutkan sesuai warna sehingga buta warna tidak bisa mengkonfigurasikan kabel ketika dibutuhkan.

Maka dibuatkan alat mempermudah dokter untuk menampilkan / menerapkan tes buta warna menjadi cepat dan akurat. Cara kerja mikrokontroller atmega 328 berbasis arduino menjadi alat untuk tes buta warna. Cara kerja infrared IR wireless remote control untuk mengganti petugas pegawas .

Penelitian ini bertujuan Menerapkan alat tes buta warna dengan menggunakan mikrokontroller secara otomatis untuk menghindari prosedur yang cukup lama. Menerapkan mikrokontroller atmega 328 sebagai alat tes buta warna untuk menghindari kemungkina kesalahan yang dikerjakan secara manual oleh petugas. Menerapkan infrared IR wireless remote control sebagai petugas pengawas.

Menurut H. Santoso Mikrokontroller sering dikenal dengan sebut $\mu \mathrm{C}$, uC, atau MCU. Terjemahan pengertian lainnya disebut, mikrokontroller adalah komputer yang berukuran mikro dalam satu chip IC (integrated circuit) yang terdiri dari processor, memory, dan antarmuka yang bisa diprogram. Jadi dengan menerapkan alat tes buta warna dengan menggunakan mikrokontroller secara otomatis untuk menghindari prosedur yang cukup lama. Menerapkan mikrokontroller atmega 328 sebagai alat tes buta warna untuk menghindari kemungkinan kesalahan yang dikerjakan secara manual oleh petugas. Serta menerapkan infrared IR wireless remote control sebagai petugas pengawas [1].

\subsection{Pengenalan Buta Warna}

Menurut R. Kurnia Salah satu gangguan yang terjadi pada mata adalah buta warna. Buta warna adalah suatu keadaan dimana seseorang tidak dapat membedakan warna tertentu yang bisa dibedakan oleh orang dengan mata normal. Seseorang yang menderita buta warna dapat disebabkan oleh kelainan sejak lahir atau akibat penggunaan obat-obatan yang berlebihan. Buta warna umumnya diderita oleh laki-laki,sedangkan wanita hanyalah sebagai gen [2]: 1-2.

Menurut R. Kulshrestha and R. K. Bairwa Buta warna adalah masalah penglihatan warna di mana seseorang kekurangan untuk mengenali warna seperti merah, hijau dan biru. Untuk melihat sesuatu ada fotoreseptor pada retina mata manusia, yang melewatkan informasi cahaya ke otak. Ada dua jenis fotoreseptor: Batang dan kerucut Kerucut bertanggung jawab untuk penglihatan warna sementara batang tidak sensitif terhadap warna [3].

Menurut Pharma and Bio Sciences Buta warna adalah genetika X-linked yang umum kekacauan. Namun, sebagian besar tirai warna tetap ada tidak terdeteksi pada populasi umum karena tidak ada pemeriksaan yang tepat. [4].

\section{METODE PENELITIAN}

\subsection{Perancangan Mekanik}

Peracangan mekanik yang akan dibuat merupakan sebuah desain kontruksi dan susunan dari komponen - komponen mekanik yang akan digunakan untuk membangun dalam pembuatan alat. Yang Akan dipasang perangkat hardware yang diperlukan untuk membangun seperti Arduino Uno, KA 390 power supply adaptor 48V 2A sebagai masukan daya ke Arduino, LCD display 16X2 sebagai keterangan jawaban, thermal printer $58 \mathrm{~mm}$ sebagai bukti dari jawaban. 


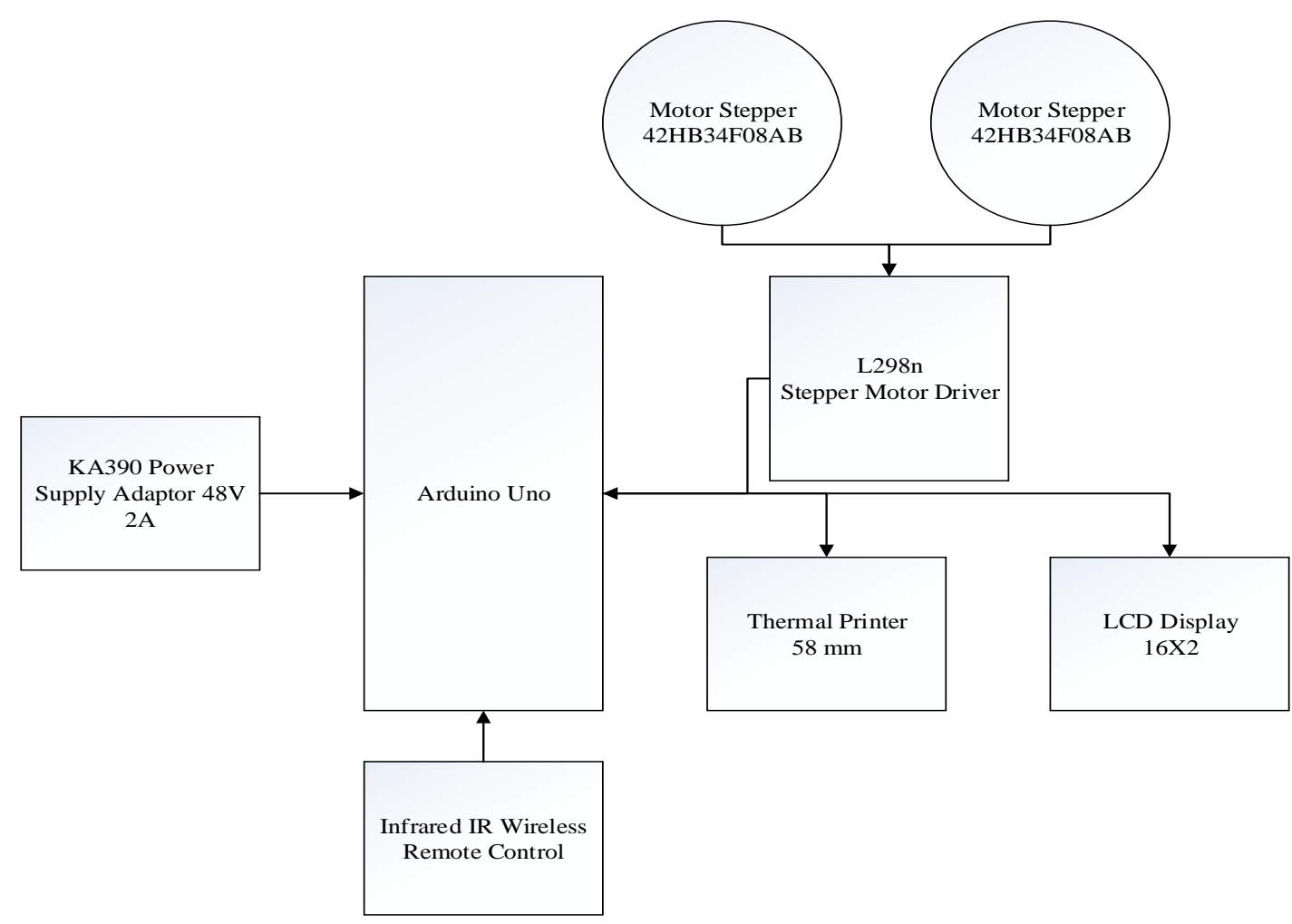

Gambar 1. Perancangan Mekanik

\subsection{Perancangan Elektrik}

Perancangan elektrik menjelaskan hardware elektronika yang digunakan untuk membangun dalam pembuatan alat atau produk, contoh dari komponen hardware tersebut seperti:

a. Arduino Uno berfungsi sebagai pengendali yang mengatur jalannya proses kerja dari rangkaian elektronik digital yang mempunyai masukan dan keluaran yang dikendalikan dengan sebuah program.

b. KA 390 power supply adaptor 48V 2A berfungsi daya untuk Arduino.

c. Motor stepper $42 \mathrm{HB} 34 \mathrm{~F} 08 \mathrm{AB}$ sebagai penggerak roll kertas.

d. L298n stepper motor driver sebagai penggatur kinerja motor stepper 42HB34F08ab.

e. IC LM 2596 pengatur step down tengangan arus listrik yang masuk ke Arduino.

f. Thermal printer $58 \mathrm{~mm}$ sebagai bukti dari jawaban yang ditampilkan pada layar LCD display $16 \times 2$.

g. LCD display 16X2 sebagai informasi dan keterangan.

h. Infrared IR wireless remote control sebagai perintah input yang akan ditampilkan pada LCD display 16X2 dan Thermal printer 58 dan juga untuk menggerakan Motor stepper 42HB34F08AB

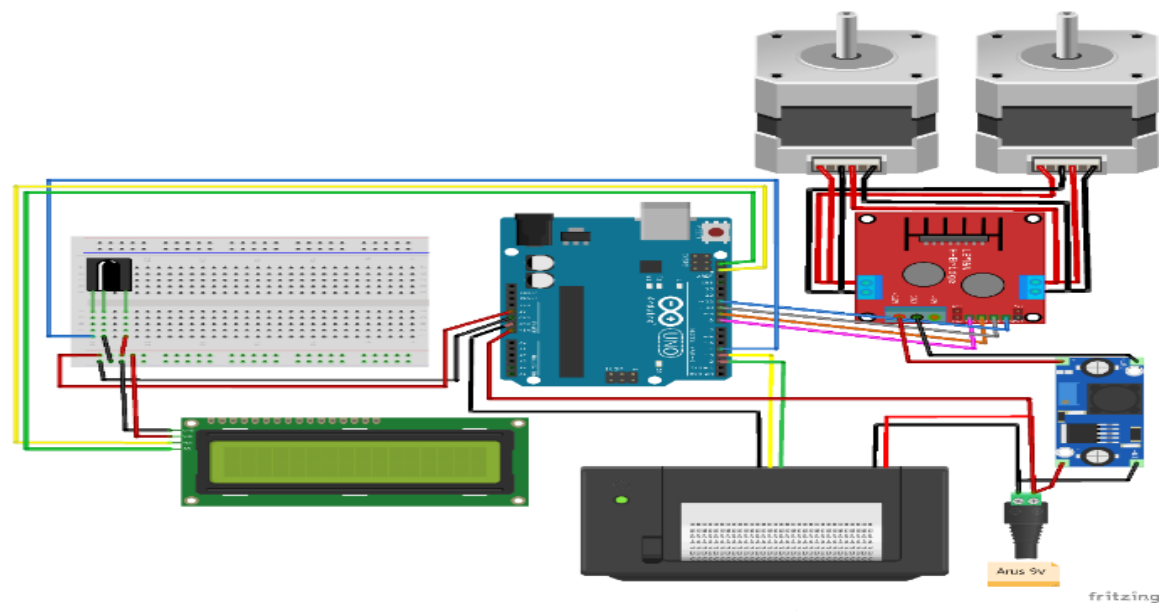

Gambar 2. Perancangan Electric 


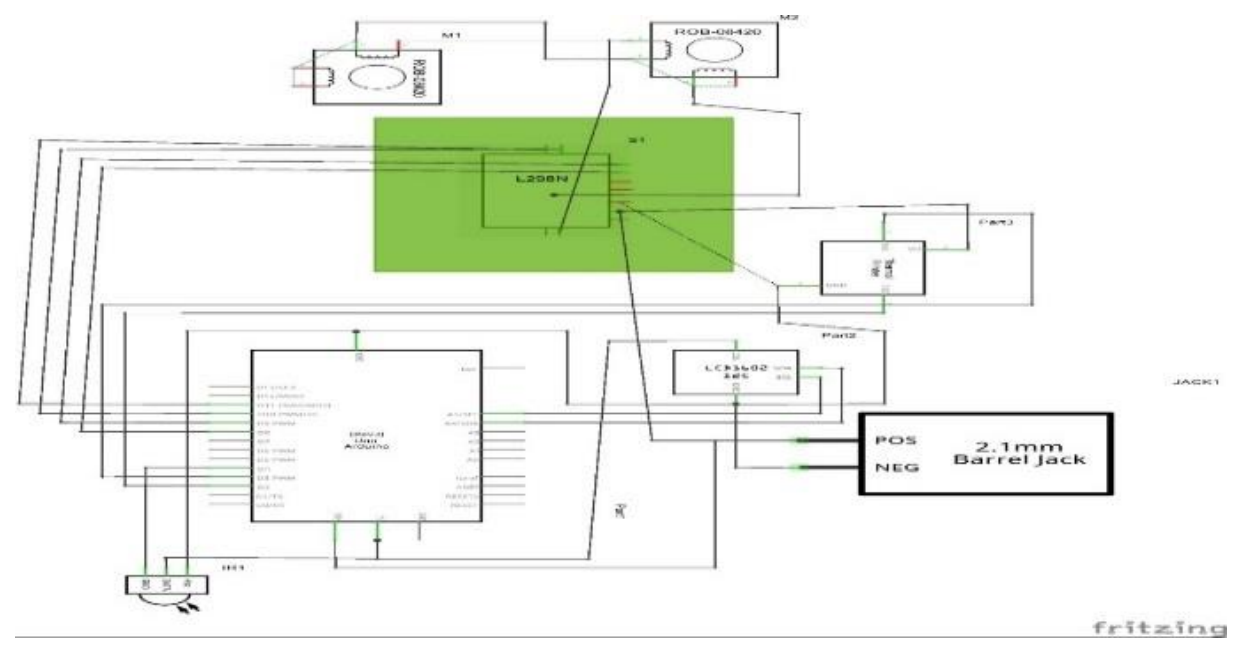

Gambar 3. Perancangan Electric

\subsection{Desain Produk}

Desain produk adalah suatu bentuk desain yang terdiri dari beberapa komponen yang digunakan untuk membuat sebuah project dan berfungsi sebagai panduan untuk membuat sebuah alat. Disini terdiri atas:

a. Infrared IR wireless remote control untuk mengakses perintah inputan.

b. Proses perintah inputan akan di proses oleh arduino dan di implemtasikan ke Motor stepper 42HB34F08AB.

c. Kertas buta warna adalah media yang akan untuk mengetahui buta warna atau mata normal.

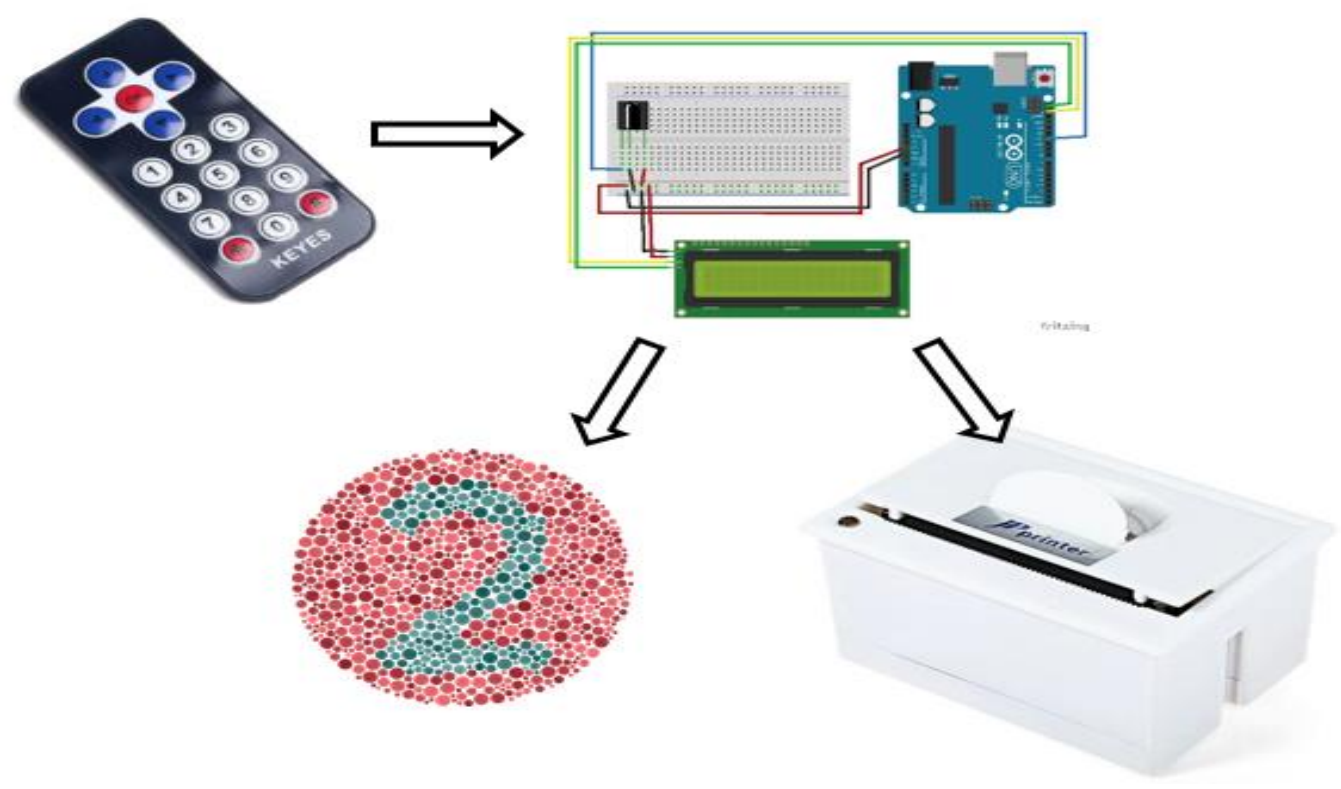

Gambar 4. Blok Diagram Sistem 


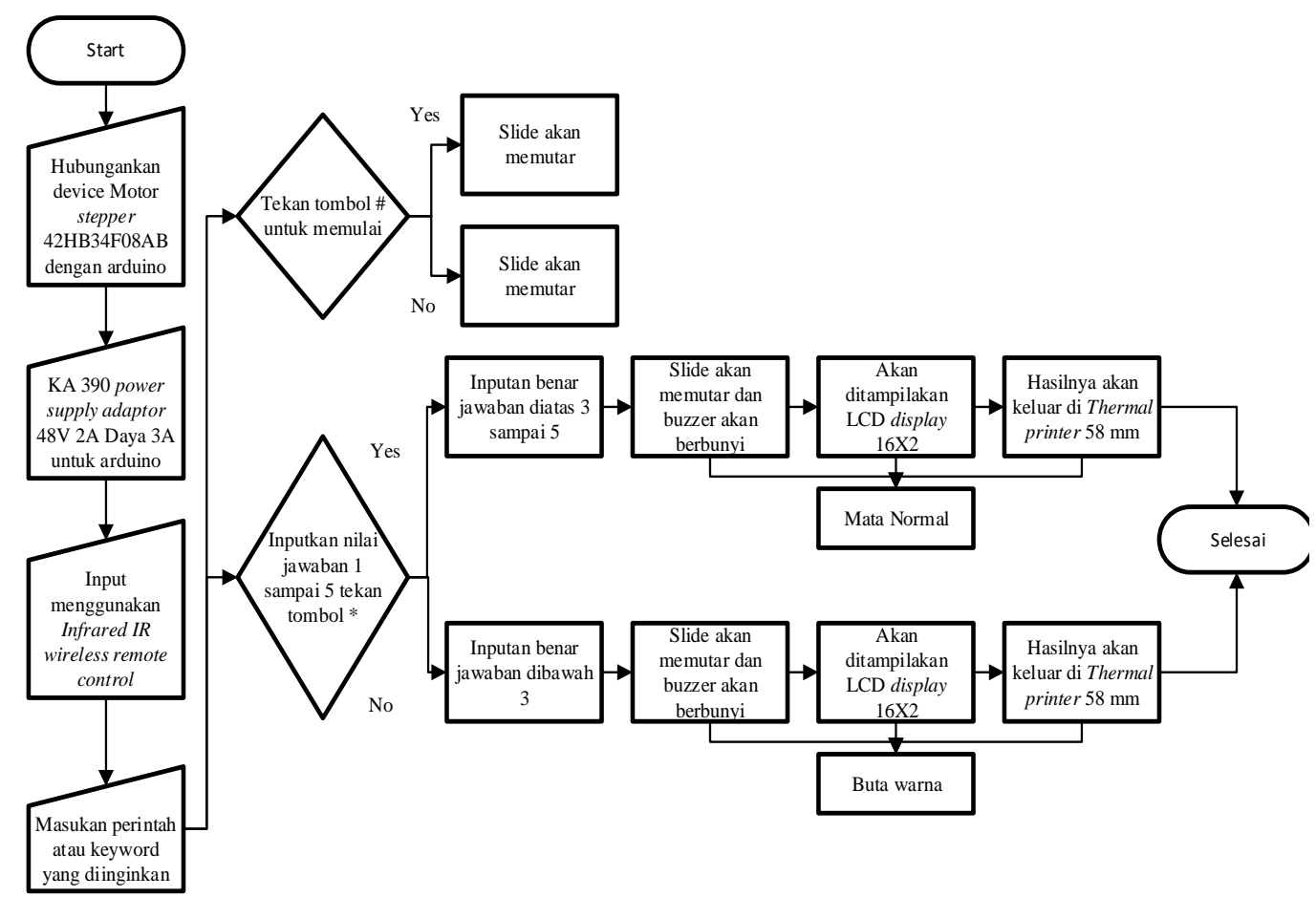

Gambar 5. Aliran Sistem Tes Buta Warna

\subsection{Arduino IDE}

Menurut E. H. Helmi Guntoro Arduino Uno adalah board mikrokontroler berbasis ATMega328. Memiliki 14 pin input dari output digital dimana 6 pin input tersebut dapat digunakan sebagai output PWM (Pulse Widht Modulation) dan 6 pin input analog, $16 \mathrm{MHz}$ osilator kristal, koneksi USB, jack power, ICSP header, dan tombol reset [5]: 2.

Menurut B. Wong Mikrokontroler adalah komputer pada chip yang diprogram untuk melakukan hampir semua kontrol, pengurutan, pemantauan, dan menampilkan fungsi. Karena biayanya yang relatif murah, itu menjadi pilihan alami bagi perancang. Mikrokontroler dirancang untuk menjadi semua itu dalam satu [6].

Menurut A. Sugiharto Arduino IDE adalah sebuah software yang digunakan untuk menulis, mengcompile menjadi kode biner dan meng-upload ke dalam memori mikrokontroler. Adapun yang memepengaruhi suatu kinerja dalam penyimpan memori mikrokontroller yaitu delay[7].

Menurut N. Junuardi Delay adalah waktu yang dibutuhkan untuk proses pengiriman dari satu titik ke titik lain yang menjadi tujuannya [8]. Menurut S. W. Limantara IoT adalah di mana benda-benda disekitar dapat saling berkomunikasi melalui jaringan internet [9]: 2 .

Menurut M. Ichwan Arduino ini merupakan sebuah board mikrokontroler yang didasarkan pada ATmega328. Arduino UNO memuat semua yang dibutuhkan untuk menunjang mikrokontroler, mudah menghubungkannya ke sebuah komputer dengan sebuah kabel USB atau mensuplainya dengan sebuah adaptor AC ke DC atau menggunakan baterai untuk memulainya [10]: 4.

Menurut T. Nusa Mikrokontroller 328 adalah salah satu mikrokontroler keluaran dari ATMEL yang mempunyai arsitektur RISC (Reduce Instruction Set Computer) yang mana setiap proses eksekusi data lebih cepat dari pada arsitektur CISC (Completed Instruction Set Computer) [11]. .Menurut W. Purnama Infrared receiver adalah deretan cahaya gelombang elektromagnetik yang intensitas cahayanya berada di bawah cahaya tampak. Infra merah ini merupakan cahaya yang dipancarakan dari Light Emitting Diode (LED) [12].

Menurut R. Kadir Motor stepper adalah perangkat elektromekanis yang bekerja dengan mengubah pulsa elektronis menjadi gerakan mekanis diskrit [13]. Menurut Falani Driver motor adalah salah satu perangkat umum yang digunakan untuk kendali motor DC. Driver motor ini yang nantinya bertugas mengendalikan arah putaran maupun kecepatan motor DC yang akan dikendalikan [14]. Menurut Ramadhan Printer thermal ini berfungsi seperti pada printer biasanya yaitu dapat mencetak karakter huruf, angka dan barcode [15]. 
Perancangan eletrik ini berisi rangkaian elektrik dimana cara implementasikan dan uji pada sebuah alat dengan sistem kerja dan desain rancangan alat.

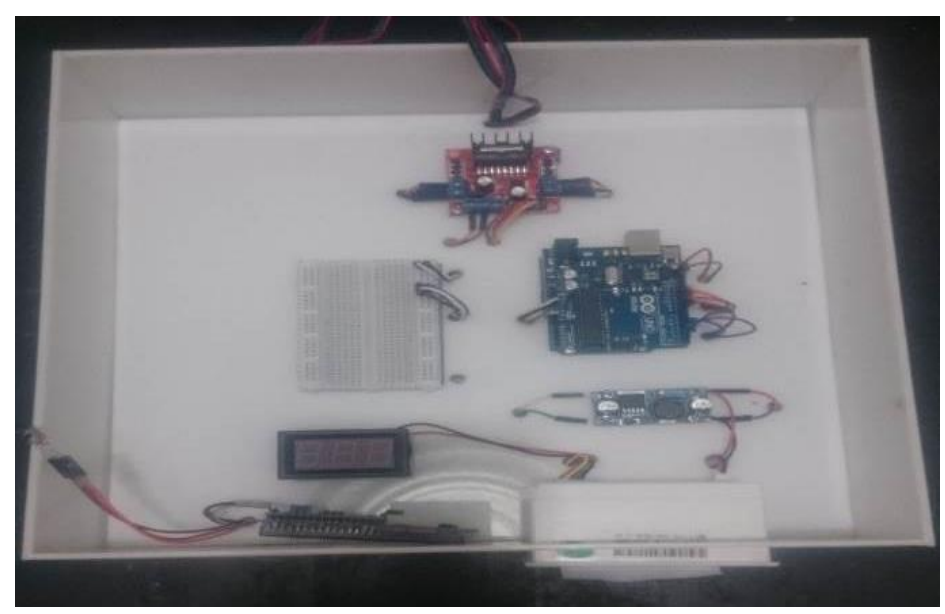

Gambar 6. Hasil Perancangan Electrik

Arduino dan Motor Stepper 42HB34F08AB dipasang dengan kabel dengan pajang $50 \mathrm{~cm}$ untuk memungkinkan letak dari Motor Stepper 42HB34F08AB untuk menggeroll kertas bisa disesuaikan letaknya dengan kebutuhan penggunaan. Selanjutnya akan tampil di layar LCD display $16 \mathrm{X} 2$ dengan tampilan "Selamat Datang" selanjutnya Inputan tombol HX 1838 Receiver Module IR pada remote tekan tombol "OK", setelah menekan tombol "OK" arduino akan memberikan perintah ke Motor Stepper 42HB34F08AB untuk menggeroll kertas sesuai dengan yang di perintah oleh remote HX 1838 Receiver Module IR. Perintah selanjutnya Akan tampil di layar LCD display 16X2 perintah untuk kepemilihan jawaban di layar LCD display 16X2 akan muncul notification text lanjut untuk penginputan tekan tombol "OK" lagi untuk menginput jawaban pertama. Disini Motor Stepper 42HB34F08AB akan mulai menggeroll kertas sesuai inputan jawaban pertama dengan pemilihan angka buta warna yang sudah ditentukan, kembali itu di remote control user akan menginputkn angka buta warna yang sudah disesuaikan dengan inputan angka buta warna dengan menekan tombol angka pada remote control yaitu contoh inputan angka " 28 ", selanjutnaya tekan tombol "OK” untuk melanjutkan kesoal jawaban kedua sampai jawaban keenam.

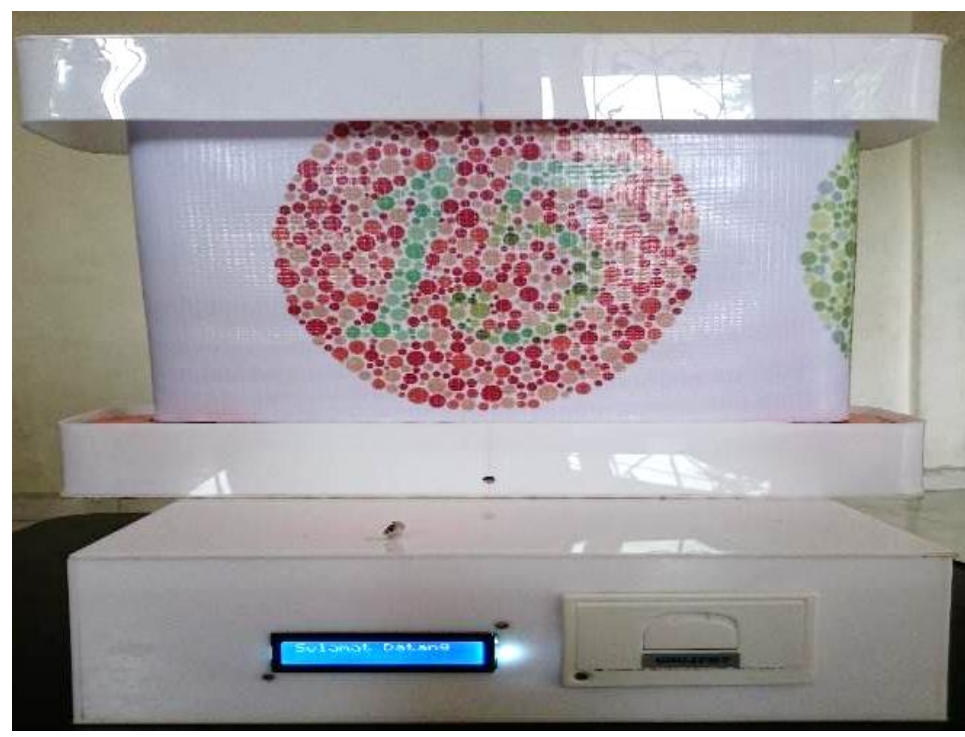

Gambar 7. Hasil Rancangan 


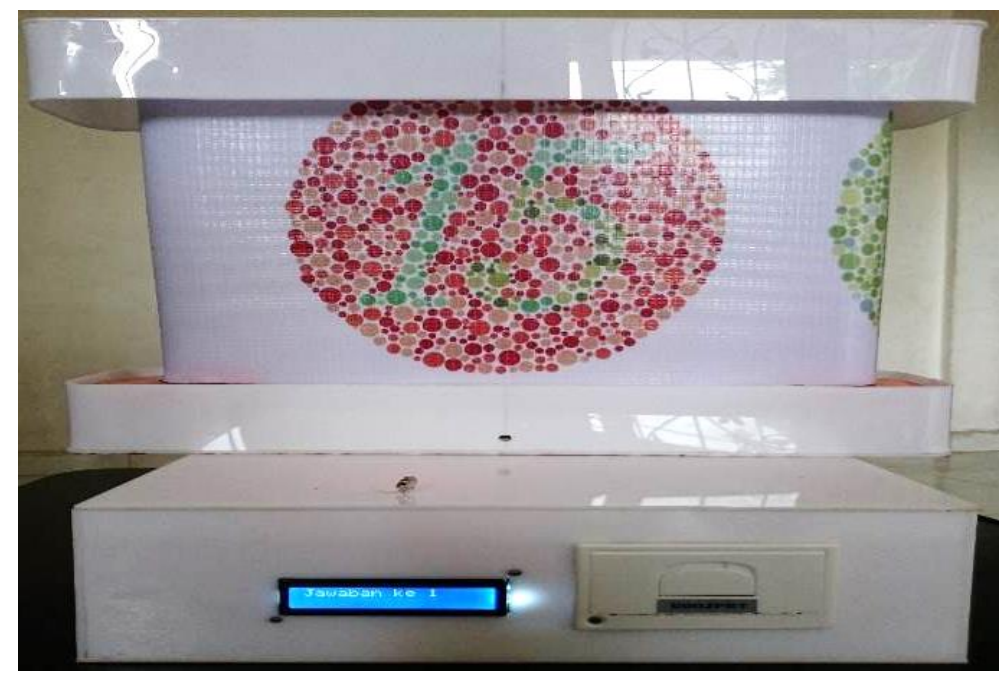

Gambar 8. Hasil Rancangan

Seperti gambar diatas setelah melakukan awalan user di perintahkan tekan tombol "OK" untuk lanjut masuk kesoal yang menuju "Jawaban ke 1" perintah ini langsung akan menginputkan nilai jawaban yang tertera pada kertas roll angka buta warna contoh angka buta warna yang tertera pada gambar diatas adalah "15" dengan menekan tombol pada remote control IR yaitu angka "1" dan "5", setelah melakukan inputan.ketas roll angka buta warna akan berputar menuju jawaban nilai dari "Jawaban ke 2" sampai selanjutnya "Jawaban ke 6".

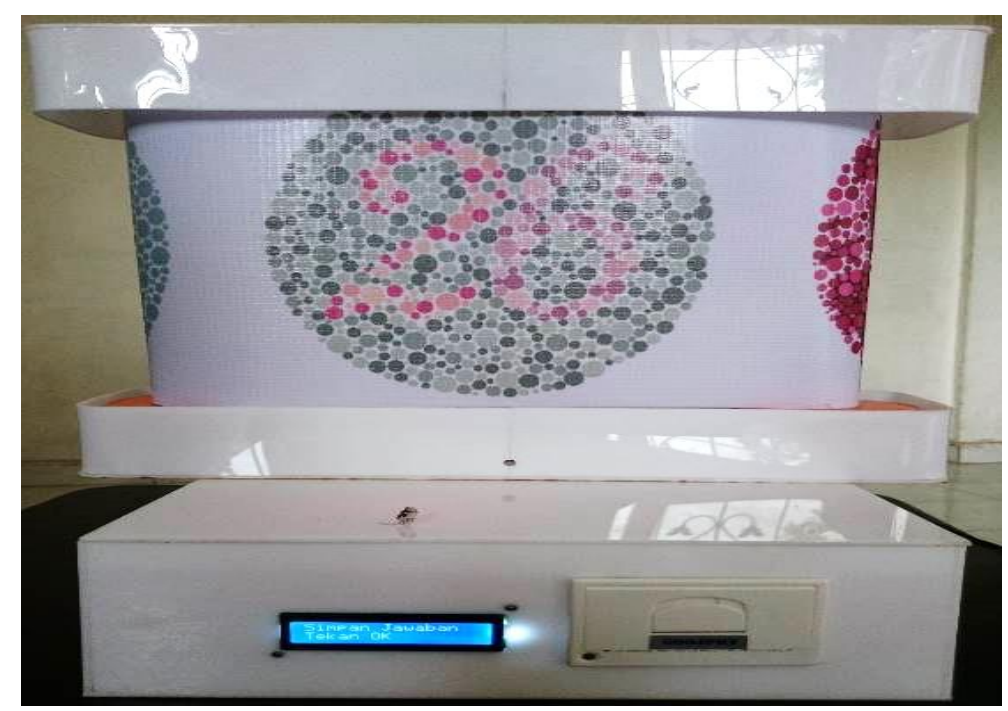

Gambar 9. Hasil Rancangan

Seperti gambar diatas Setelah menjawab semua "Jawaban ke 1" sampai dengan "Jawaban ke 6", kemudian ada perintah pada LCD display 16X2 untuk menekan tombol "Simpan Jawaban Tekan OK" yang tertera pada remote control IR.

Dan seperti gambar di bawah ini hasil dengan menjawab jawab 1 sampai 6 dengan jawaban benar kurang dari 2 jawaban benar dengan hasil "Maaf !! Mata anda tidak Normal". 


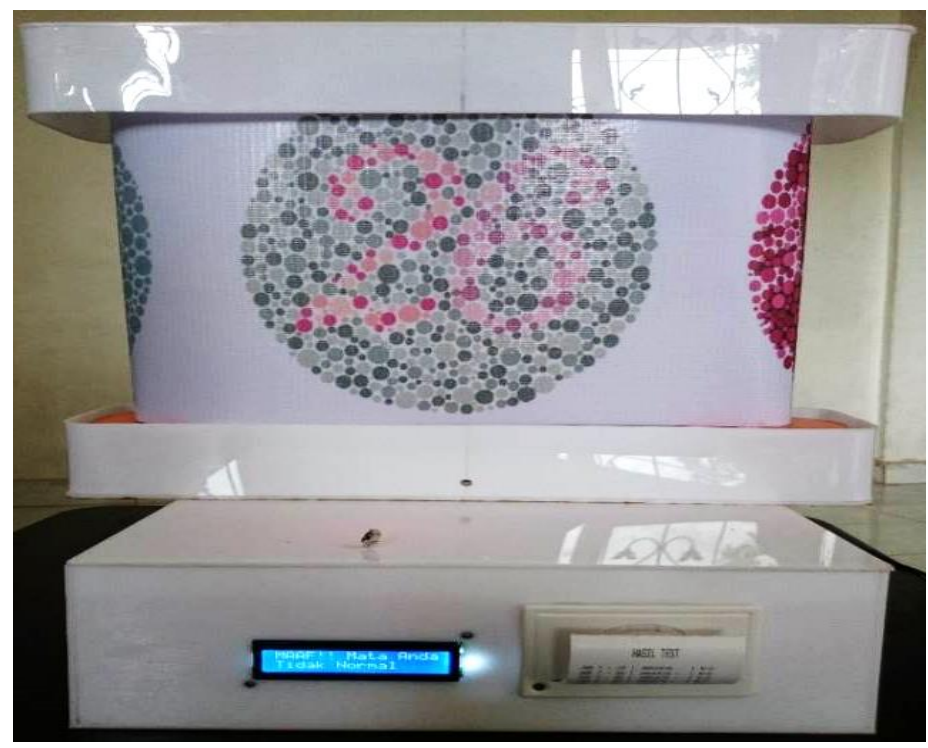

Gambar 10. Hasil Rancangan

Seperti gambar di bawah ini hasil dengan menjawab jawab 1 sampai 6 dengan jawaban benar lebih dari 3 jawaban benar dengan hasil "Selamat !! Mata anda Normal".

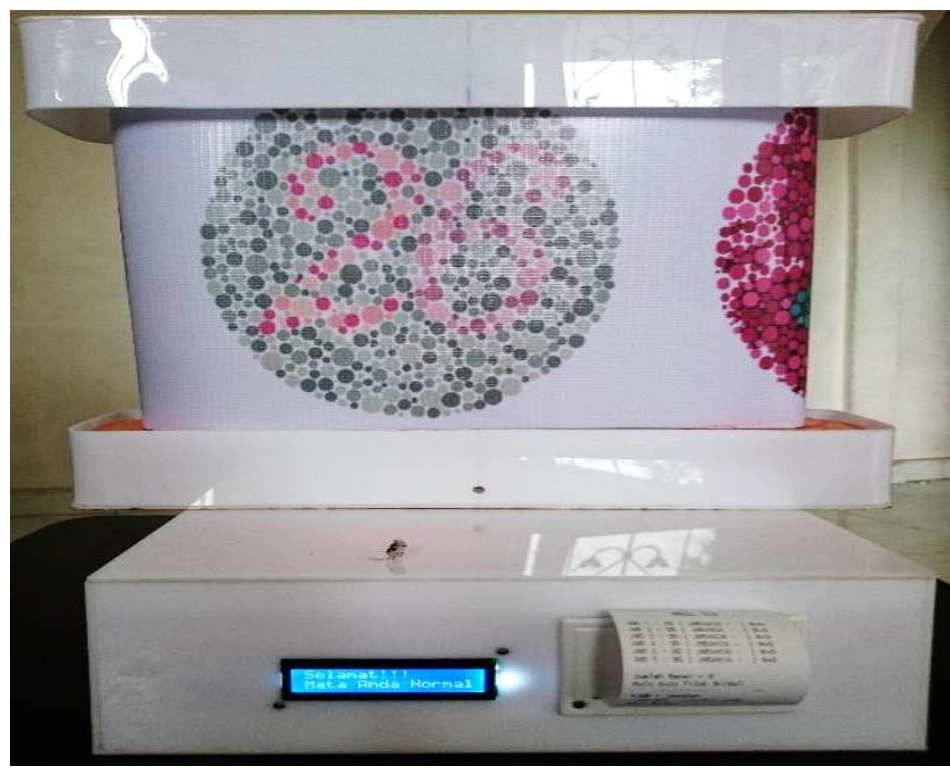

Gambar 11. Hasil Rancangan

\section{HASIL DAN PEMBAHASAN}

\subsection{Hasil Pengujian Alat Tes Buta Warna}

Pengujian ini dilakukan untuk menguji kinerja alat yang telah dibuat. Semua rangkaiana electrik digabungkan dengan mikrokontroller kemudian diberi inputan arus power supply (dengan inputan 9 Volt 5 Ampere). Selanjutnya memasukan inputan dengan menekan tombol remote yang sudah terprogram di arduino uno. Kemudian pengujian setiap masuk ke HX 1838 Receiver Module IR dengan memasukkan inputan pada tombol remote untuk memberikan perintah yang akan menggerakan motor stepper dengan kertas akan menggeroll angka tes buta warna. Tabel dibawah ini menampilkan hasil pengujian pada alat. 
Tabel 1. Hasil pengujian sistem

\begin{tabular}{|c|c|c|c|c|c|c|}
\hline Inputan & & & Yang diingikan & Hasil & & Kesimpulan \\
\hline $\begin{array}{l}\text { Tersedia } \\
\text { jawaban }\end{array}$ & ada & & $\begin{array}{l}\text { Apa bila menjawab } 2 \\
\text { benar }\end{array}$ & Buta warna & & $\begin{array}{l}\text { Mata tidak } \\
\text { normal }\end{array}$ \\
\hline $\begin{array}{l}\text { Tersedia } \\
\text { jawaban }\end{array}$ & ada & 6 & $\begin{array}{l}\text { Apa bila menjawab } \\
\text { lebih dari } 3 \text { benar }\end{array}$ & $\begin{array}{l}\text { Tidak } \\
\text { warna }\end{array}$ & buta & Mata normal \\
\hline
\end{tabular}

\section{KESIMPULAN}

Berdasarkan hasil dari beberapa tahap perancangan, pembutab, dan pengujian alat tes buta warna dapat di ambil kesimpulan antara lain:

a. Berdasarka penelitian ini telah dapat dibuat sebuah alat tes buta warna dengan menggunakan mikrokontroller arduino uno seperti yang sudah dibahas sebelumnya, arduino dapat diterapkan dengan baik pada peralatan perkantoran maupun rumah sakit khusus pada alat tes buta warna.

b. Alat ini berfungsi sebagai alat yang otomatis karena adanya Infrared IR wireless remote control sehingga bisa diatur dari jarak jauh.

c. Dari hasil pengujian yang dilakukan, pengunaan alat dengan menggunakan Infrared IR wireless remote control memiliki kelebihan dibandingkan dengan menggunakan metode manual karena pengguna lebih efektif dan efisien. Metode manual hanya akan membuat tingkat kesalahan menjadi lebih besar yaitu dengan membuka atau membolak - balikan kertas melalui petugas atau suster yang menjaga.

\section{DAFTAR PUSTAKA}

[1] H. Santoso, Panduan Praktis Arduino untuk Pemula. Jawa Timur: Elang Sakti, 2016.

[2] R. Kurnia, "Penentuan Tingkat Buta Warna Berbasis His Dengan Banyak Warna Pada Citra Isihara," Semin. Nas. Apl. Teknol. Inf. 2009 (SNATI 2009), vol. IV, no. 1, pp. 54-77, 2009.

[3] R. Kulshrestha and R. K. Bairwa, "Review of Color Blindness Removal Methods using Image Processing," vol. 2, no. June, pp. 18-21, 2013.

[4] "International Journal of Pharma and Bio Sciences ISSN PREVALENCE OF CONGENITAL COLOR BLINDNESS AMONG UNDER GRADUATE MEDICAL STUDENTS," vol. 6, no. 4, pp. 1114-1116, 2015.

[5] E. H. Helmi guntoro, Yoyo Somantri, "Rancang Bangun Magnetic Door Lock Menggunakan Keypad Dan Solenoid Berbasis Mikrokontroler Arduino Uno," Electrans, vol. 12, no. 1, pp. 39-48, 2013.

[6] B. Wong, "Color blindness,” Nat. Methods, vol. 8, no. 6, p. 441, 2011.

[7] A. Sugiharto, "Sistem Kontrol Nirkabel pada Surveillance Mobile Robot Jurnal Disprotek," Univ. Teknol. Yogyakarta, vol. 8, pp. 8-15, 2017.

[8] N. Januardi, "Implementasi Quality of Service, Limit Bandwidth Dan Load Balancing Dengan Menggunakan Firmware Dd-Wrt Pada Router Buffalo Whr-Hp-G300N,” vol. 9, no. 1, pp. 404-413, 2018.

[9] S. W. Limantara, A. D., Candra, A. I., \& Mudjanarko, "Manajemen Data Lalu Lintas Kendaraan Berbasis Sistem Internet Cerdas Ujicoba Implementasi Di Laboratorium Universitas Kadiri,” Pros. Semnastek, no. November, pp. 1-2, 2017.

[10] M. Ichwan, M. G. Husada, and M. Iqbal Ar Rasyid, "Pembangunan Prototipe Sistem Pengendalian Peralatan Listrik Pada Platform Android,” J. Inform., vol. 4, no. 1, pp. 13-25, 2013.

[11] T. Nusa, S. R. U. A. Sompie, and E. M. Rumbayan, "Sistem Monitoring Konsumsi Energi Listrik Secara Real Time Berbasis Mikrokontroler," Tek. Elektro dan Komputrer, vol. 4, no. 5, pp. 19-26, 2015.

[12] W. Purnama, V. Hendrico, D. Ariyono, D. Virgian, and S. Yudha, "Sistem Quality Control Gudang Menggunakan Sensor DT-I/ O Infrared Receiver 991-121 , Push Email dan Mikrokontroler Arduino Uno pada PT Multiprima Food," no. 2, pp. 107-117, 2017.

[13] R. Kadir, R. Berikang, and S. Manado, "Simulasi Jemuran Otomatis Berbasis Mikrokontroler," pp. 815-820, 2018. 
[14] M. Status, G. Pada, A. Z. Falani, S. Budi, and K. Kunci, "Robot Line Follower Berbasis Mikrokontroler Atmega 16 denganMenampilkan Status Gerak Pada LCD,” Narodroid, vol. 1, no. 1, pp. 85-93, 2015.

[15] S. H. Ramadhan, S. Hadiyoso, and Y. S. Hariyani, "Rancang Bangun dan Implementasi Pada Sistem Panggilan Antrian di Pukesmas Bojongsoang Berbasis Arduino Design and implementation of dialing queue in Puskesmas Bojongsoang based on Arduino,” vol. 3, no. 3, pp. 1969-1978, 2017. 